\title{
ATP5F1B Gene
}

National Cancer Institute

\section{Source}

National Cancer Institute. ATP5F1B Gene. NCI Thesaurus. Code C118525.

This gene plays a role in both oxidative phosphorylation and ATP synthesis. 